Hydrol. Earth Syst. Sci. Discuss., 4, 1917-1946, 2007 www.hydrol-earth-syst-sci-discuss.net/4/1917/2007/

(C) Author(s) 2007. This work is licensed under a Creative Commons License.
Hydrology and Earth System Sciences Discussions

\title{
Watershed regulation and local action: analysis of the Senegal River watershed management by a regional organisation and public participation
}

A. M. Sène, S. Bonin, and O. Soubeyran

Institut de Géographie Alpine, Laboratoire PACTE - Territoires, Grenoble, France

Received: 30 May 2007 - Accepted: 12 June 2007 - Published: 28 June 2007

Correspondence to: A. M. Sène (amsenea@yahoo.fr)

HESSD

4, 1917-1946, 2007

Analysis of the Senegal River watershed management

A. M. Sène et al.

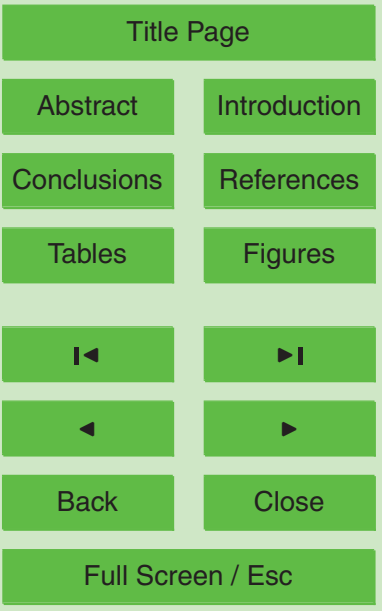

Printer-friendly Version

Interactive Discussion 


\section{Abstract}

Several social scientists have dealt with the usefulness of a participative approach in development plans. The call for sustainable development has increased the focus on this type of approach in a very classical way, which is the case for the creation of new 5 water tanks. Most of these scientists have also pinpointed the major difficulties and failures faced during the execution of this new approach in developing countries. This study is a concrete example which underlines the lack of this type of approach as far as water management in the Senegal River is concerned, mainly in relation to watershed. We base our study on the analysis and criticism of the regional organization OMVS 10 (Organization for the Development of the Senegal River) which is in charge of water management in the Senegal River. The results of the study can, therefore, be summed up as follows: (i) An on-site direct observation, individual interviews, group discussion and information analysis point out the lack of participation of local people in water management in the Senegal River and, in general, the harmful socio-economic impacts 15 resulting from it. (ii) The reasons for this lack of participative approach are mainly due to the model set up by the OMVS in terms of water management in the Senegal River, a model that has excluded or tackled in a very light way the issue of public participation in decision-making through out its juridical and regulation instruments. (iii) Elements of consideration on some measures, which could possibly improve the level of participation of local people in river water management.

\section{Introduction}

\subsection{Research area}

With a basin of more than 300000 square meters, the Senegal River is formed by the junction of many rivers; the most important of which are the Bafing, the Bakoye and the Faleme. The Senegal River crosses the high plateau in the north of Guinea, the

\section{HESSD}

4, 1917-1946, 2007

Analysis of the Senegal River watershed management

A. M. Sène et al.

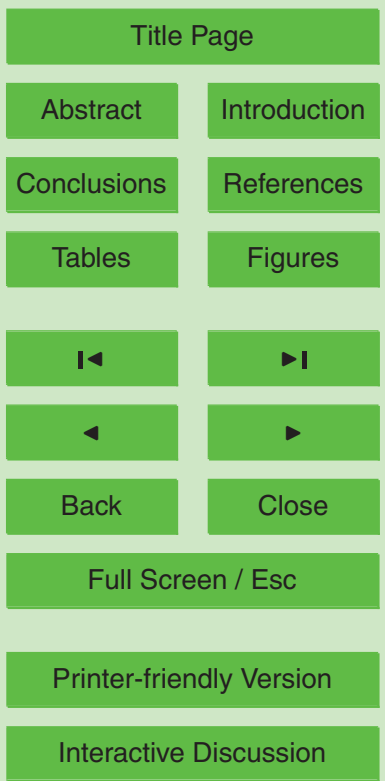


west of Mali, and the southern regions of Mauritania before flowing into the borders of Senegal (Fig. 1). By moving away from its source, the river is subjected to the growing rain shortage combined with a double gradient south-north and east-west, which draws away the impairment of its hydrologic behaviour subjected to inter-annual varia5 tions. The hydro-pluviometric aspect of the arid and semi-arid environment of the river and the importance of its hydraulic potential justifies its interests to the different countries and the local populations. So, at the beginning of 1960s, the States concerned with the watershed of the Senegal River (Guinea, Mali, Mauritania and Senegal), had found the real need to set up an organisation which would be able to implement some 10 regulating mechanisms of the river in order to avoid the harmful consequences of climatic vagaries across the region. It is in this context that the neighbouring countries, along the river, created the Inter-states Committee in 1960, which was replaced by the Organization of the Riverside States of the Senegal River (Organisation des Etats Riverains du Sénégal, OERS) in 1970. Following the withdrawal of Guinea from this 15 organisation, the Organization for the Development of the Senegal River (Organisation pour la Mise en Valeur du Fleuve Sénégal, OMVS) substituted for OERS in 1972.

In rainy seasons, the river causes serious floods that destroy crops and houses while during drought, production is affected by the disturbance of the dynamic flood / drop in the water level. Besides, salt water goes up to more than 200 kilometres from the mouth of the river, thus, restricting the possibilities of farming in the zone. Facing these natural problems, member States of the OMVS, in collaboration with foreign development partners have deemed it necessary to build big dams in order to regulate the speed of the river and to promote its water resources by means of hydro-electricity production. The availability of a volume of water in the valley makes sailing possible across the river and the multiplication of annual agrarian campaigns. The main achievements carried out on the Senegal River include the Diama and the Manantali dams. The construction of these two dams stretched respectively from 1981 to 1986 for the first and from 1982 to 1988 for the second. The dams required common and huge works at very expensive costs. They brought about important socioeconomic and
HESSD

4, 1917-1946, 2007

Analysis of the

Senegal River

watershed

management

A. M. Sène et al.

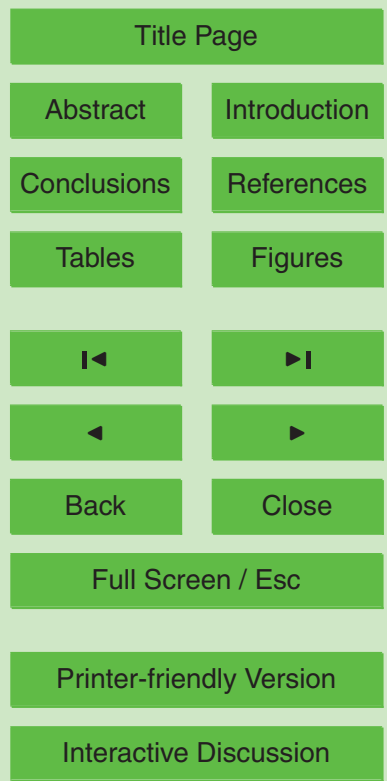


environmental changes to the whole valley. These two dams are a landmark among all other achievements related to water management in the Senegal River (Lericollais, 1989; Engelhard, 1991; Muneera et al., 1994; OMVS and IRD, 1999).

The implementation of these achievements has been accompanied by a solid regu5 lation which ensures the rational and equitable exploitation of the resources of the river. To reach this objective, several conventions have been ratified by the member States of the OMVS, the most decisive of which concerned local population participation stipulated by the Charter of waters and the Standing Committee of Waters (Commission Permanente des Eaux, CPE), ratified respectively in 2002 and in 2003.

10 The principle of local population participation, broadly mentioned in these last decades by several international treaties, is of great interest to the OMVS, which tends nowadays to translate the most part of these treaties into new conventions drawn up by the member States (Sène, 2006). But in the very worrying African context, characterized by underdevelopment with all its harmful impacts on political, social and economic 15 plans, the application of international or regional agreements collide in general with several obstacles (Kiss, 1997; Kiss and Shelton, 2001). In this continent, all the current specialists of development support commonly the failure of participative approach. These specialists agree about the fact that this failure would be in most cases linked to a "top - down" approach which does not allow the populations to appropriate really 20 the techniques of management of their resources (Eldin and Milleville, 1989; Dupré, 1990; Mathieu, 1993; Baré, 1994, 1997). The watershed of the Senegal River lies indeed in this difficult context. How does governance of this river take into account the principle of local population participation in decision-making? This principle is certainly mentioned in the Charter of waters of the river and in the implements of environmental management as the Reduction and Monitoring Program of Impacts on Environment of Senegal River (Programme d'Atténuation et de Suivi des Impacts sur l'Environnement de la mise en valeur du fleuve Sénégal, PASIE), but is its application efficient?

This study allows not only highlighting the exclusion of local populations in the decision-making process in relation to the water of the Senegal River and the harmful
HESSD

4, 1917-1946, 2007

Analysis of the Senegal River watershed management

A. M. Sène et al.

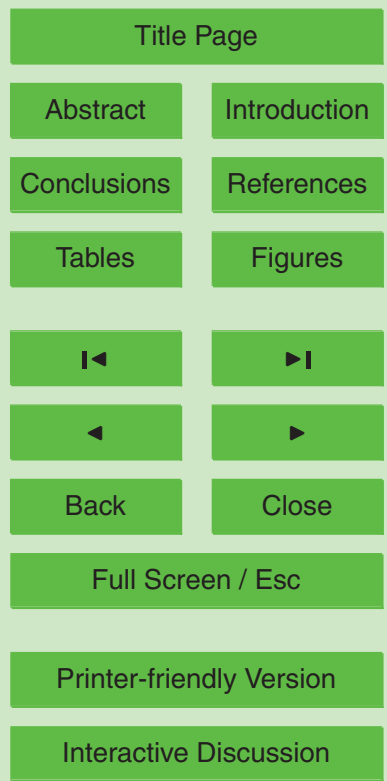


impacts which result from it, but it also shows that the OMVS, the regional organisation entrusted with the water management of the Senegal River, bears high responsibility in this respect. So, it questions the problem of effectiveness of institutions in Africa regarding natural resources management.

$5 \quad 1.2$ Research methodology

We have referred in this study to a methodology generally employed in social sciences and natural sciences: document analysis supplemented by on-site observation, discussions and interviews. The existing literature on river resource use and management, policy documents related to river and land use, field reports on rural livelihoods and 10 farming systems were an important source of information. We have based our primary hypothesis, concerning the absence of a real local public participation in water resources management of the area feeding on Senegal River, on an oriented analysis of available documents dealing with this issue. Contrary to non-oriented analysis which rather depends on seeking and deducing hypotheses, the oriented analysis aims at the verification of a certain hypothesis and at specifying its objective and its ends. As such, this oriented analysis is more rigorous and systematic and it has an accessible technique. All the authors mentioned in this article (Sect. 2 and Sect. 4) criticize directly or indirectly the weak local participation of riverside populations. We have based our assumption that this weakness is basically related to and institutional problem, notably the 20 top-down approach advocated by the regional organisation OMVS in its management practices, on the analysis of a number of documents concerned with the regulation and the governance of the Senegal River (Sect. 3). Such a quantitative and qualitative analysis enabled us to highlight new tendencies, mainly exhibiting the actual intention of OMVS representatives to conform to the standards of participation suggested by the 25 great international conventions. These tendencies have resulted in the creation of new rules (Charter of waters, 2002) and new structures (National and Local Committees of Coordination, 1997). As a matter of fact, by examining the contents of these documents, we noticed that before the year 1997, the date of the creation of the Committees

HESSD

4, 1917-1946, 2007

Analysis of the Senegal River watershed management

A. M. Sène et al.

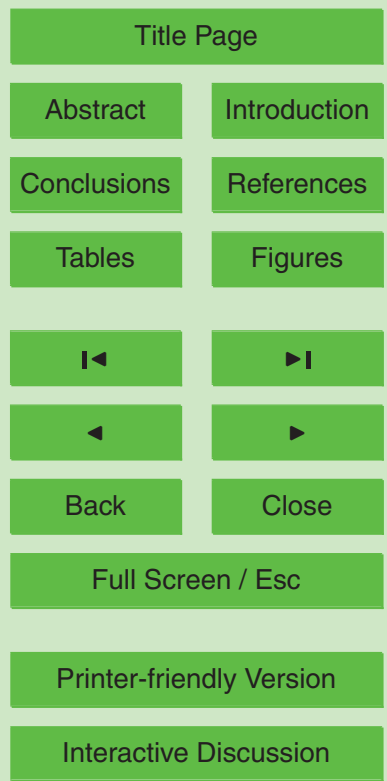

EGU 
of Coordination, the governance of the Senegal River did not actually involve the public in decision-making process. In Sect. 4, in addition to the discussion, the analysis of documents shows, however, that despite the obvious political intention to involve the public in river water management, no remarkable progress is achieved: this remains 5 more or less an illusion.

Not only did fieldwork facilitate access to many written texts, but it also allowed us to conduct analytical or diagnostic interviews. Such interviews have, in fact, a specific objective. They do not simply aim at an explanation of what is taking place for the purpose of deducing a general theory, but at looking for the reasons for the sake of finding a 10 certain remedy (Grawitz, 2001). Semi-structured and open-ended interview techniques were used in order to obtain in-depth information. We interviewed people in different situations, some were organized individually, and others in groups and sub-groups with men and women at different levels. We were able to directly observe activities organized by OMVS in some villages concerned with the watershed of the Senegal River 15 such as committee meetings, to gain insights into socio-political processes and the ways in which people make decisions in meetings and discussion forums. In particular, we observed how meetings were conducted, who decided which activities were to be undertaken, who were the speakers and whose interests they represented, whether the local populations played any role in the process and whether their voices were heard.

ect. 2 is primarily based on analytical interviews that enabled us to come out with a certain diagnostic or new hypothesis: the lack of public participation stems originally from an institutional problem (the governance of the river by OMVS). This same section contributed as well to new solutions that were useful in Sect. 4.

We are first going to examine the importance of the principle of local population 25 participation in water management of the Senegal River by drawing attention to the lack of its application and the harmful consequences that follow. Then we will analyse the model of water management of the OMVS and the main regional agreement which underlines the current principles of water management of the Senegal River (Charter of waters). Finally, we will conclude by a debate that will suggest new ideas that help
HESSD

4, 1917-1946, 2007

Analysis of the Senegal River watershed management

A. M. Sène et al.

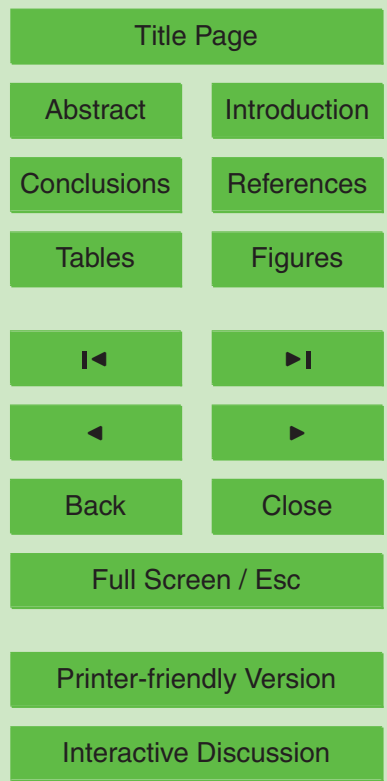


promoting public participation in this field of work.

HESSD

\section{Principle of local population participation: definition and current state in the watershed of the Senegal River}

\subsection{Theoretical presentation of the principle of local population participation}

5 According to the last estimates, there are 261 international watersheds, 60 of which are found in Africa. The growing pressure on water resources in this continent makes urgent the development of principles and tools which enable solving conflicts between users and States as well as preserving resource and aquatic environment (Lecornu, 1998; World commission on dam, 2000; Caubet, 2002). Among general principles 10 newly adopted on the international scene, there is the principle of population participation in decision-making (principle 10 of the Declaration on environment and sustainable development, Rio, 06/1992; principle 6 of the Convention on access to information, Convention on public participation in decision-making, and access to justice in environmental matters, Aarhus, Danemark, 25/06/1998; principle 24 of the Convention on the law of the non-navigational uses of international watercourses, New York, 05/1997).

The participative approach during these last decades mobilized a lot of works of researchers analysing conflicts or impacts of developments, but also civil servants made responsible for defining political orientations of the natural resource management or economic development (for an overview of those works, from a French point of view: Labranche and Warin, 2003). Options kept for the planning of development emphasize the importance of the true participation of populations in choices concerning their own life and their own future. (Cernea, 1998; Scoones and Thompson, 1999; Aubert, 2002; Cling et al., 2002; Levy, 2002; D’Aquino and Seck, 2003).

Among the numerous proposals of definitions of the principle of public participation, we find Dubosc's (2001) the most comprehensive. It considers participation as a principle that raises the question of power, especially, in the sense that decision-makers
4, 1917-1946, 2007

Analysis of the Senegal River watershed management

A. M. Sène et al.

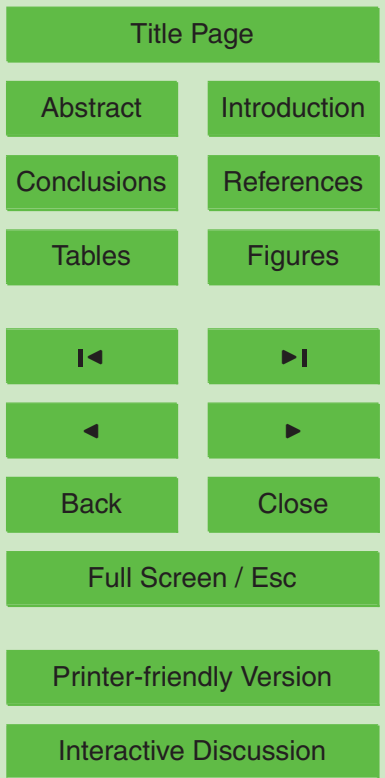

EGU 
agree at least to share part of their power with the population. So, this population power can result from a conquest. In that case, populations gain permission to be acknowledged and accepted as interlocutors of authority. This power can also result from an answer to a proposal granted by authority. Populations enter then in struc5 tures, procedures, processes conceived by authority to discuss and interact with them. The creation of the decentralized coordination committees (CNC: National Committees of Coordination and CLC: Local Committees of Coordination) with the installation of PASIE at the level of the Senegal River watershed concerns this case.

This power includes four degrees. First, there is the power of information: it is the 10 power to issue and to spread information, along with the one issued and spread by authorities (elected members, technicians, administrations, and experts). The second is consultation: it is the power to express one's opinion, before settling authority. It is the example of the role of observant newly granted to certain users of the society within CPE, advisory organ of OMVS, by the Charter of waters of the river ratified by 15 member States in 2002. The third concerns the power of consultation which ensures sharing out of instruction of a file between the authority and the populations, who are in a way also considered experts (expertise of usage). Finally, there is real participation. It corresponds to the power of making decision, instead of authority or jointly with her; the most developed form of participation being then a kind of "co-decision" (Eyben and Ladbury, 1997; Hussein, 1997; Lane, 1997; Nelson and Wright, 1997). In the watershed of the river, we can mention powers assigned to the Senegalese Sugar Company (CSS). Besides its role as an observant within CPE, OMVS grants power to this private company to regulate the bridge-dam located in Richard Toll according to its needs in water.

\subsection{A "weak" public participation in decision-making}

During 1970s, OMVS made a study of public participation in the activities of water development and management of the river. The analysis of this study shows the interest or even the necessity for OMVS to involve the public through institutions such as ru-
HESSD

4, 1917-1946, 2007

Analysis of the Senegal River watershed management

A. M. Sène et al.

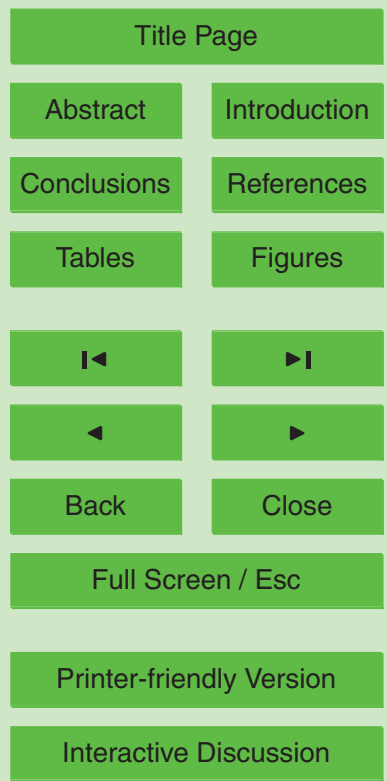

EGU 
ral and local council, and cooperatives. The study concludes that public participation in the management of development activities attached to the river is necessary to get satisfactory results irrespective of financial and technical means (Guerber, 1986).

In Senegal, different laws concerning territorial organization (administrative and local 5 reform in 1972 and 2002; transfer of competences in regions, communes and rural communities in 1996), on structures and social organizations (reform of cooperatives in 1984), on economic policy (liberalization and disengagement of State in 1986) and on national property (law on national property in 1964, reclassification of pioneer zone into local zone in 1987) contributed to the transfer of many and diversified powers in 10 basic structures and gave to local communities a better sense of responsibility (Coly and Niang, 2000).

In spite of all these very appropriate territorial reforms in terms of public participation, rural communities and urban communes don't really participate in water management, and don't receive information on decisions about the resource management. Fall et al. (2001, p.20) point out that: "as the rural communities, the urban communes of the watershed of the Senegal River are not involved in water management and have no information and data at their disposal on the river management although they were questioned permanently on the possible problems caused by the dams."

One of the explanations that could justify this insufficiency of the public participation

would be probably of an institutional nature. That management system set up to manage the water resource is focused on structures of the regional organization (OMVS) and its member States. On a regional scale, CPE centralizes the needs of every country, examines and decides, in association with the representatives of States, quantities of water to plan and to place at the population's disposal. Senegal is represented by 25 the SAED (Society for the development and exploitation of the lands of the Senegal River's Delta and from Senegal River's Valleys and Faleme) which takes responsibility before every agrarian campaign of providing the estimate of water required by the riparian population, and it announces it then to CPE. So, the local organizations of the society (rural Organizations, Economic Interests Groups, NGO, etc) are kept away from
HESSD

4, 1917-1946, 2007

Analysis of the Senegal River watershed management

A. M. Sène et al.

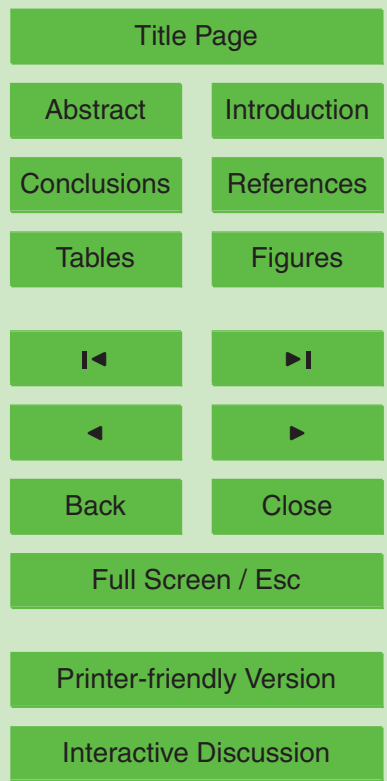


decision-making in water management. The lack of public participation in river water management has a main consequence: the lack of appropriate structures that are able to defend all their interests. The national actors representing them are in general subjected to reserve obligations for diplomatic reasons in comparison with orientations and 5 decisions of CPE, a member of a regional organization (OMVS).

Besides the important national development organisations (SAED for Senegal and SONADER for Mauritania) which are represented within CPE, we also notice representation among its private users. The latter are represented in Senegal only by the CSS and the SDE (Society of Waters). The site of the CSS and its strong establishment in 10 this area together with its economic weight enables the company to have the power of decision as to the opening and the closing of the bridge dam located in the delta of the river. This form of inequality, maintained by the OMVS, with the participation of the different actors and users of water, is considered to be an injustice by the local population and constitutes a source of tension. In fact, populations and different unions that represent them consider that the CSS regulates the opening and the closing of the bridge dam not according to the interest of all the local users but only on the basis of its own needs. Another very sensitive problem put forward by the CSS is the flowing of the draining water in the river or the lake of Guiers. The representatives of the CSS advocate that for ten years water is to be treated before its introduction into the river, while the riverside population still defends an opposite view by pointing out its harmful impacts on health and activities (fishing, agriculture, and farming). They think that this situation will persist because of their absence from decision-making with respect to water management.

Being aware of this reality, the OMVS has recently created different strategies in order to involve the population in development activities related to the exploitation of the river, and especially to allow them to benefit from hydro agrarian work (dams of Diama and Manantali). These strategies are implemented by the CLC at the level of villages. Despite these recent efforts made by the OMVS to involve the local population in decision-making, the situation concerning their participation has become a real
HESSD

4, 1917-1946, 2007

Analysis of the Senegal River watershed management

A. M. Sène et al.

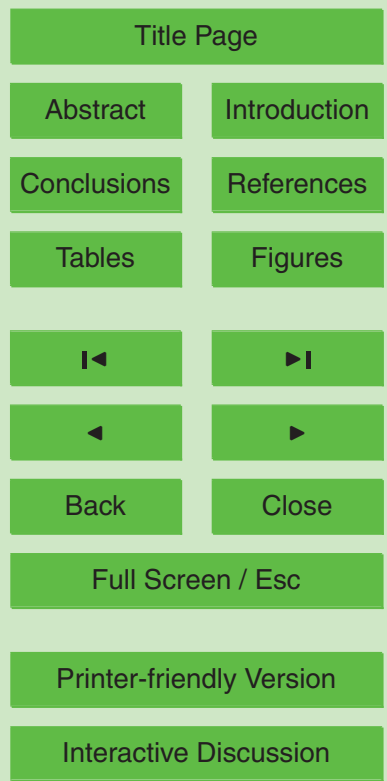


concern as illustrated by researches on the valley of the river (Tangara, 1998; Baldé, 1999; Coly, 2003) and also our discussions with riverside population. In an interview, some of them expressed their views as follows:

"... we do not have time to go to meetings and take part in discussions, and we 5 also do not know what is to be discussed, and how to discuss [it]. In the past, we were free attending assemblies, but did not properly understand the decisions taken. We were not consulted about the rules and regulation of the river use and management." (riverside population group discussion, mars 2006)

\section{Regulation and governance of the Senegal River}

\subsection{Historical background on water management}

The juridical arrangements of the OMVS are composed of four basic conventions signed before the implementation of the dams (Table 1): the Convention of the 11 March 1972 amended in relation to the Status of the Senegal River; the Convention of the 11 March 1972 amended about the creation of the OMVS; the Convention of 21 December 1978 related to the Legal status of Common Works and the Convention of 12 May 1982 related to the modalities of financing of Common Works.

This first group was supplemented in 01/1997 after the construction of the dams by the Convention of 7 January 1997 which concerns the creation of the Agency for the Management and Exploitation of the Diama; the Convention of 7 January 1997 which creation of the Agency for the Management of Power of the Manantali; and finally in 2002, the Charter of waters was ratified by the member States (Table 1).

These conventions define the dispositions which permit planning, study, building, working and renewal of the common infrastructure of the Senegal River watershed, on the institutional, organizational, financial, juridical and technical level (OMVS, 2006).

25 Among them, only the recent Charter of waters (2002) and the CPE rules, established for the first time by the resolution $n^{\circ} 89 / \mathrm{CM} / \mathrm{N}$ of $05 / 01 / 1978$ of OMVS then updated in

\section{HESSD}

4, 1917-1946, 2007

Analysis of the Senegal River watershed management

A. M. Sène et al.

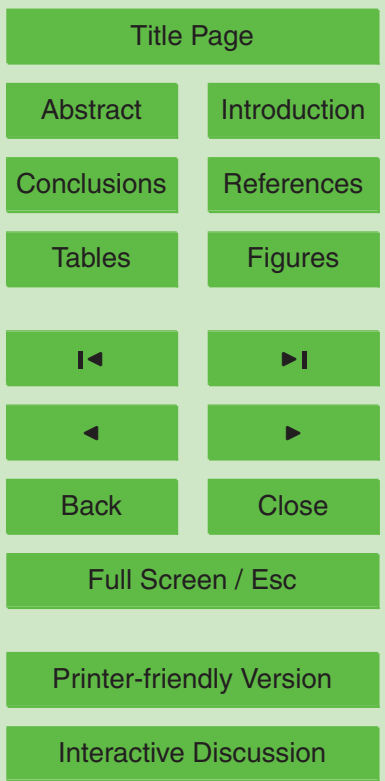

EGU 
$10 / 2003$, treat the question of public participation in decision-making in the management of the Senegal River. As such, the regulation context, before the dams, is marked by the absence of reference to public participation.

3.2 The Charter of waters: strong reference to international statements and new com5 mitments linked to the participation of the non-state actors in decision-making

This Charter was adopted on 28 May 2002 by the Conference of the State leaders of the OMVS and ratified by the Parliaments of Member States. It consists of a common declaration and three related annexes. The first annex defines the optimum strategy of the projected sharing out of water resources and the two others constitute the manual for the management of the Manantali and the Diama.

The main objectives of the Charter are to fix principles and modalities for the sharing out of the waters of the Senegal River among the different areas of use; to determine rules related to the preservation and to the protection of environment, particularly as regards fauna, flora, and ecosystems; and finally to define the framework and the 5 modalities of public participation in decision-making as far as water resources management of the river is concerned (article 2). We can therefore underline that both environment and public participation in decision-making have a fundamental role in the objectives of the Charter.

\subsubsection{Reference to international statements}

20 The article 24 of the Convention of New York on the Law of the Non-Navigational Uses of International Watercourses (1997) is related to the creation of a "mixed mechanism of management" of international watercourses. This frame of management could correspond to CPE (Fig. 2). However, the creation of CPE (5 January 1978) is prior to the Convention of New York. In fact, the first article of CPE dating 1978 shows that the Commission is only composed of representatives of member States (two representatives by State), and that every delegation can be assisted by national experts. On the
HESSD

4, 1917-1946, 2007

Analysis of the

Senegal River

watershed

management

A. M. Sène et al.

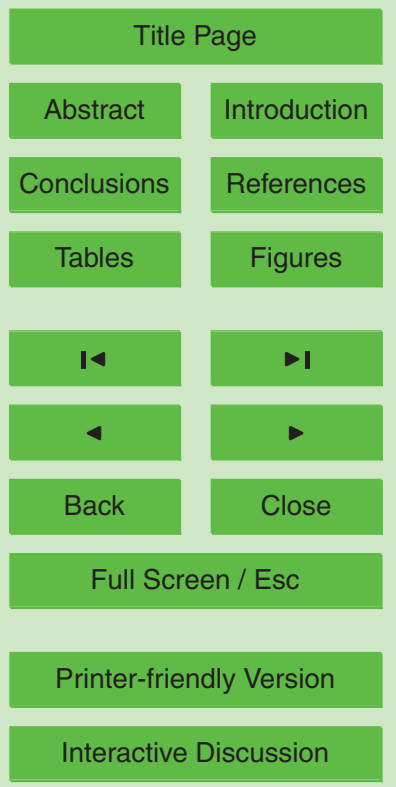


other hand, the Charter of waters introduces into Article 23 that observer's status to CPE would be authorized by the Council of ministers at High commissioner's proposition to certain entities of member States. These entities which have observer's status participate in a real way in the work of CPE. These following persons can benefit from 5 this status: representatives of the users; representatives of local communities; representatives of NGOs; representatives of the decentralized Committees of coordination. Furthermore, the Charter enunciates in its Article 13 the principles of better informing and training the public.

Nevertheless, we could mention several other international instruments which tackle 10 the question of participation and that have probably inspired the Charter (Fig. 2): Principle 10 of Declaration of Rio on environment and sustainable development (1992); Article 10 of the Convention on biodiversity (1992); Convention on access to information, Convention on public participation in decision-making, and access to justice in environmental matters (1998). Article 13 of the Convention on biological diversity which 15 encourages education, information and sensitization of the public to the conservation and sustainable use of biodiversity also seems to inspire Article 13 of the Charter.

\subsubsection{Non-state actors to be part of the decision-making process}

Commitments reported by Article 23 of the Charter show distinctly the qualifications of the non-state actors invited for participating in river water management activities 20 (Fig. 2): users or local populations at first. However, these still do not have direct representatives in CPE. Their absence could result either from the lack of information on the new regulations of OMVS, that is, from an ignorance of the Charter and its contents, or simply from the problem of organization relating to the choice of the representatives. In fact, the diversity of users, their activities, their ethnic origins and their very large geographic distribution (watershed of the river) make difficult any action aiming at uniting them in order to choose representatives likely to inform them on decisions taken within OMVS, and also to report their complaints within CPE, even if these users are already organized in groups (Economic Interests Groups, Producers' Organizations... ).
HESSD

4, 1917-1946, 2007

Analysis of the Senegal River watershed management

A. M. Sène et al.

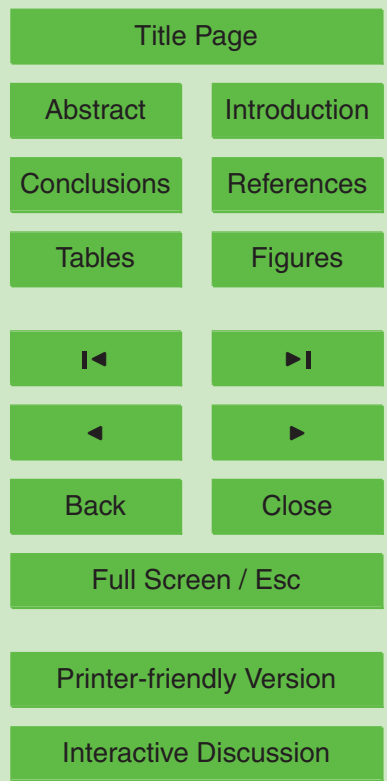

EGU 
Then, the second group of actors, whose member States plan to give more attention to decision-making, is formed by territorial communities. In Senegal, the legislative texts involve territorial communities in the management of environment, natural resources and regional development. New competences have been transferred to ter5 ritorial communities since 22 March 1996 (law $n^{\circ}$ 96-07). Then, regions, established as local communities, are consequently endowed to new competences; communes and local communities add new competences to the general ones they have since their creation. However, concerning the management of the national or international watercourses, mainly the Senegal River, this law grants no qualification to territorial 10 communities except the role of the police of waters granted to communes. It stipulates that the region has the competence to manage continental waters except the case of national or international watercourses (Article 28) ; and to the commune, the protection of underground and superficial water resources (article 29). With this effect, the decree $n^{\circ}$ 96-1134 (Article 33) of 27 December 1996 attributes competence to the commune

to fix the conditions of waste water discharge through an authorization issued by the mayor based on the opinion of the municipal council. The goal is, therefore, to duplicate the participation of local communities in a horizontal way (in all members State) and in a vertical way (in the regional areas of decision-making).

Finally, the last category of actors involved in the process includes NGOs and decen20 tralized committees of coordination. NGOs are very numerous and very dynamic in the activities of watershed development. The Charter aims at improving the participation of local NGOs and strengthening the collaboration with the "society" in all stages of decision-making.

\subsection{Institutional mechanisms of the OMVS and public participation in decision-making}

25 The institutional mechanisms set up in the watershed of the Senegal River revolve around the creation of a regional organization (OMVS). OMVS is responsible for the management of the river and its different organs and provides the final dispositions relating to agreements or conventions ratified by all member States.
HESSD

4, 1917-1946, 2007

Analysis of the Senegal River watershed management

A. M. Sène et al.

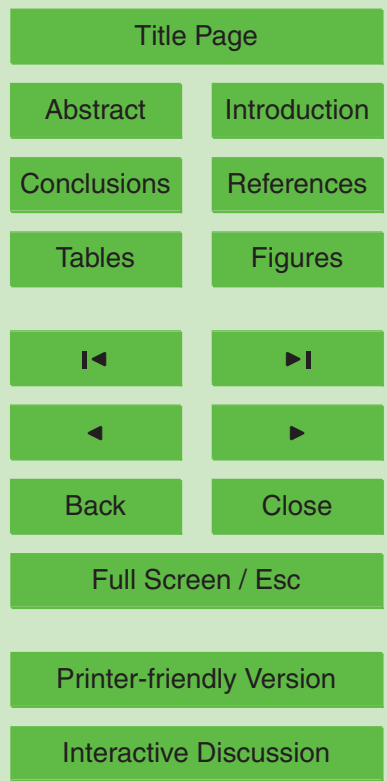

EGU 
The Convention relating to the creation of the OMVS was signed on 11 March 1972 by the State leaders of Mali, Mauritania and Senegal. The headquarter of the organization lies in Dakar, Republic of Senegal. Articles 3 and 7 of the Convention list its main organs (Fig. 3): the Conference of the leaders of States and Governments, the 5 Council of ministers, and the High commission.

- The Conference of the leaders of States and Governments is the supreme authority of the organization. It defines the policy of collaboration and development of the organization and makes decisions concerning general economic development. Decisions are taken unanimously by its members and are imposed on all

- The Council of ministers is the organ of conception and control of the organization. It makes general policies as concerns the development of the Senegal River and its resources. It also strengthens collaboration between States bordering the Senegal River. Decisions of the Council are taken unanimously by its member States and are deemed obligatory upon them.

- The High Commission is the organ of execution of the organization. It implements the decisions of the Council of ministers and gives a regular account of their execution in addition to any initiative taken within the framework of received directives and within the limits of authority delegated to it.

Besides these main permanent organs, the OMVS has advisory organs where the participation of population is accepted according to well determined forms (Fig. 3). These advisory organs are CPE, the Advisory Committee of the financers, the Regional Committee of Planning, the National Committees of Coordination (CNC) and the Local Committees of Coordination (CLC).

- CPE is composed of representatives of the member States of the organization and is an advisory organ to the Council of ministers. The local populations can be represented within this commission. Article 1 of the CPE rules shows that it is

\section{HESSD}

4, 1917-1946, 2007

Analysis of the Senegal River watershed management

A. M. Sène et al.

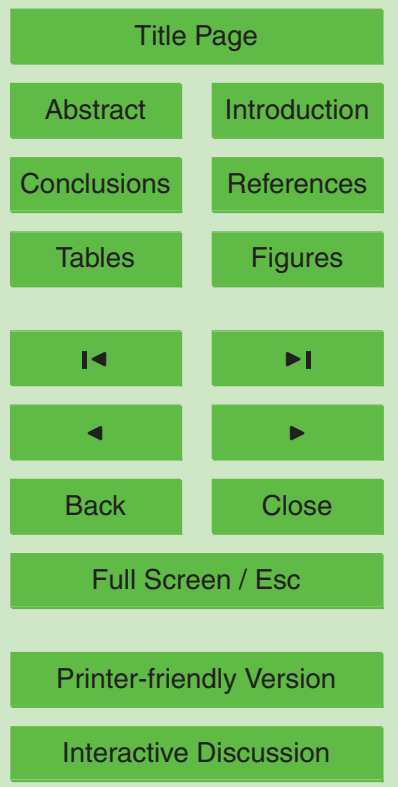

EGU 
responsible for: defining the principles and modalities of the distribution of waters of the Senegal River in the areas of use; supervising the plans of member States likely to have a negative impact on the waters of the river; intervening in the control of the use of water and the fight against pollution; periodically preparing the plan of water resources management. This plan is based on projections of the users' needs and on a simulation of the management of the system Manantali-Diama.

- The Advisory Committee of the financers unites the representatives of countries, financing institutions, and those of the OMVS. It has a role of assistance in the High Commission, mainly finding suitable means of mobilization as regards financing and human resources, and promoting exchange of information.

- The Regional Committee of Planning is composed of representatives of States. For the attention of the Council of ministers, it is also responsible for issuing an advisory opinion on the program of investment relating to the optimum emphasizing of the resources of the watershed. Then, it provides measures in coherence or even harmonization with the policies of watershed development.

The creation of CNC and CLC is recent and enters within the framework of the creation at the regional level a Piloting Committee of PASIE. As a program of action defined by the OMVS (1999), the PASIE takes measures for correction, optimization and supervision of the impacts on the environment as part of the development of the river resources. It also specifies the mechanisms of coordination, communication and monitoring which are envisaged to ensure the participation of all concerned, including local communities and NGOs, in the environmental management of the watershed. The piloting Committee of PASIE regroups at the same time representatives of States, OMVS, partners in development and the civil society. This Committee, advisory organ of the Council of ministers, is formed by an institutional assemblage that tries to respect the obligation of local population participation. It resulted in the creation of a CNC and CLC within every member State.

\section{HESSD}

4, 1917-1946, 2007

Analysis of the Senegal River watershed management

A. M. Sène et al.

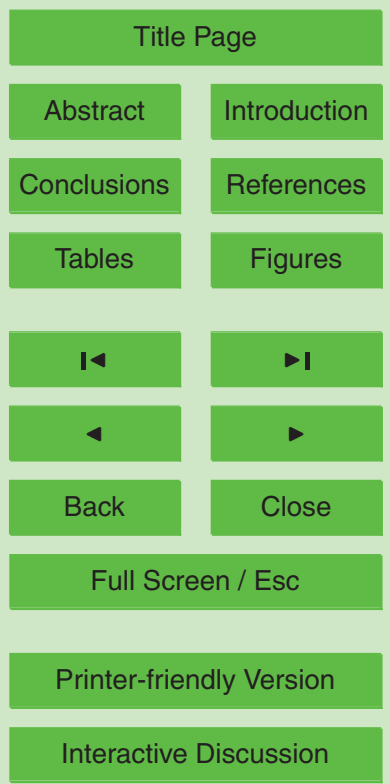


- In every country, CNC is constituted of the concerned ministries, the professional organizations, the civil society (NGOs, associations) and the representatives of the CLC. It is responsible for assuring coordination and monitoring of the actions of PASIE, as well as organizing information and mobilisation of populations at the level of every member State.

- CLC regroups, in every country, local communities, associations and professional cooperatives, representatives of the associations of young persons and women, NGOs and representatives of administrative authority. These CLC give their opinion on resources management and follow the execution of the programs of PASIE. Their opinion is transmitted to and discussed in the Piloting Committee.

A fine observation of this governance of the river points out clearly that at the top of the river management organisation (OMVS) the permanent organs ensure the definition of water management programs, their control and execution. Local populations are only represented in advisory organs. In this respect, they just have a right to be informed and to issue their opinion on programs developed and applied by permanent organs. This form of participation, very restricted, theoretically accepted by the OMVS, collides furthermore with several obstacles (broadly itemized in the following party) which make obsolete its enforcement.

\section{Obstacles to the application of public participation principle and lanes of res- olution}

The recent reforms operated by the OMVS within its implements and tools of management highlight clear commitments in favour of a better public participation. In the theoretical plan, therefore, the principle of public participation is well incorporated in the conceptualization of the new instruments of management of the Senegal River. This significant advance in public participation in the new texts of the OMVS is partly due to the work of the international community. In fact, we notice that stating this principle

Analysis of the Senegal River watershed management

A. M. Sène et al.

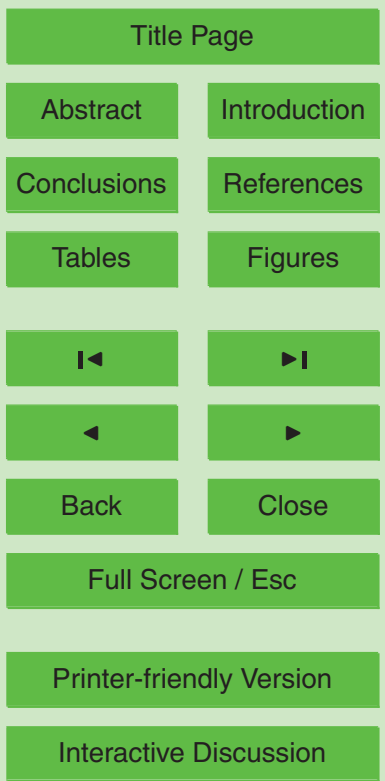

EGU 
in the Charter of waters of OMVS follows its evocation by several international declarations. The advantage of this passage from the international level into the regional or sub-regional level is that it allows passing from "soft law" to "hard law". It is necessary to mark that in the international scale, commitments within the framework of this princi5 ple of participation do not have an obligatory character, in general, while they become obligatory for member States of OMVS as soon as their introduction into conventions of the organization.

Despite the success which we can notice in the contents of the Charter of waters and the actual institutional implement of OMVS as far as participation is concerned, 10 it is important to acknowledge that as for watershed, public participation is still very deficient. A problem of application of developed measures therefore seems to come to light. On this point, the Charter presents some weaknesses. In fact, its dispositions are not accompanied by a detailed plan of its concrete application. By referring to the research made by Mvondo (2006) on the Treaty of Brazzaville relating to forest 15 Ecosystem management of central Africa, it is thought that the annex of such plan, also "hard law", in Charter, should have been appended to the main text, either in the form of a protocol of signatures, or in the form of a protocol based on the main treaty. This additional text would have had advantage at the same time to clarify better and to itemize the Charter of waters and also make easier its application.

20 Besides these problems of application of the Charter, other difficulties which contribute to decelerate or to block the application of the principle of public participation concern insufficiency or absence of education, information and training of populations. These factors were already reported by previous studies conducted on the watershed. Roche (2003, p. 86), for example, underlines their importance by showing that the train25 ing of all actors who intervene in the development of a locality is inevitable to lead to efficient results: "To answer the challenge of the institution of a real participation of the actors in the plans of development, an audacious and volunteer policy of professional training must be implemented".

By referring to the artificial risings executed in the context of the Manantali dam to

\section{HESSD}

4, 1917-1946, 2007

Analysis of the Senegal River watershed management

A. M. Sène et al.

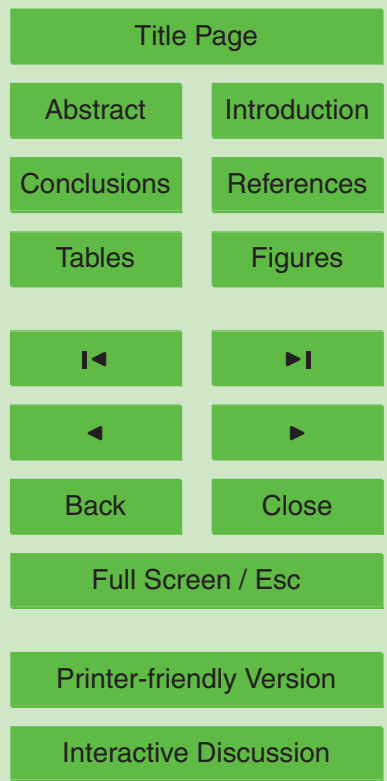


ensure a better availability of water, we pointed out that farmers are not well informed. Yet, farmers are the most concerned by these achievements. They know neither the form of the river as regards its rising nor the coasts or flows expected in the river or in its affluent or diffluent on which they depend. So, they are stuck in a situation where 5 floods are the work of nature, sudden and unpredictable, a situation where the river is partly controlled but where the farmer is surprised to see the level of waters rising, going out then rising again, or to see a second peak of flood which comes to devastate seedings.

A study accomplished by the OMVS (2001) reports that during the rainy season 10 1994-1995, the rising was very good and when fall began farmers sowed very large areas (at least in the periphery of what had to represent very large areas). A new top of flood (corresponding to the oil change of the Manantali dam) then occurred, damaging down the seedings and especially swamping over three months the zones to be sown. The expansion of this second flood was such that re-growth was not 15 possible. It completely destroyed the hopes of crops on a large part of the plains. This disaster is principally due to the lack of information and knowledge on the mechanisms of functioning of the dams by the riverside rural populations.

Moreover, in 2001, the report of Fall and al. (2001) confirms that this problem of information and communication between the OMVS and populations has always been crystal clear. It points out that populations, representatives of their organizations and the local elected representatives of the different concerned local communities do not receive any information on the quantities of water expected to fall and the periods of dropping and artificial flood. Consequently, populations are subjected to severe damage owing only to a lack of consideration of the periods of feeding the river in water from the dams. In fact, populations have only slightly or never been informed, directly and in a clear way, on the program of work edification and its future impacts on their activities and zones. In this sense, it is necessary to mention the numerous questions raised by the people we met as to power generation and its probable impact on zones located along the river. For local populations, dams have a very important

HESSD

4, 1917-1946, 2007

Analysis of the Senegal River watershed management

A. M. Sène et al.

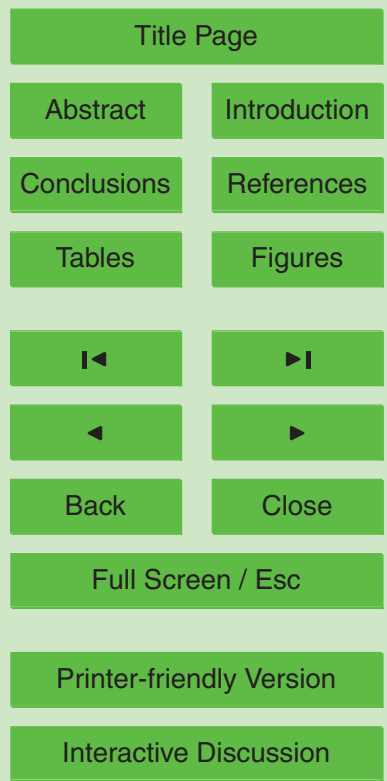

EGU 
social and economic cost as the deductions of water due to the dams changed several aspects of their agrarian production capacities and pastoral farming. Therefore, the lack of a good policy of communication in relation to populations, the principle of public participation in decision-making cannot be properly applied.

5 This communication problem of the OMVS justifies that today the Charter of waters of the Senegal River which is the present instrument of management of the watershed, is little known by actors involved in the river management. To change this reality, the OMVS must certainly multiply the organization of working groups identical to the working groups of information and exchanges on the Charter which it accomplished in 10 September 2006 in Mali with CNC, CLC and with all other actors of the civil society concerned with the watershed (Koné, 2006). So, it is necessary that the different actors be familiar with this instrument of management. It is so essential that the Article 13 of the Charter invites States and the High commission to make sure that information on the state of river waters, the measures envisaged or advocated to assure the reg15 ularity of the flow of the river and the quality of waters be accessible to the public; but at the same time, to look after the education of populations by promoting awareness programs on the Charter.

CLC and CNC were developed by the OMVS in 1999 with the intention of ensuring communication and interface of the implementation of PASIE with the local administrations and the concerned riverside populations. This objective, very restricted to these participative structures aiming at a well determined program, is not influential enough to cause a real change in public participation. It is what justifies that our on-site observations in 2006 and the recent studies on watershed (OMVS, 2001) show all the insufficiency of public participation in the watershed. Furthermore, the World Bank

25 (2000), in its evaluation of these committees, considers that in Senegal, they are still composed principally of local administration, civil servants, and local political representatives, some groups of producers and representatives of NGOs. Therefore, many people directly concerned by water management in the watershed are not represented in these committees, who in their turn are also not well represented at the level of
HESSD

4, 1917-1946, 2007

Analysis of the

Senegal River

watershed

management

A. M. Sène et al.

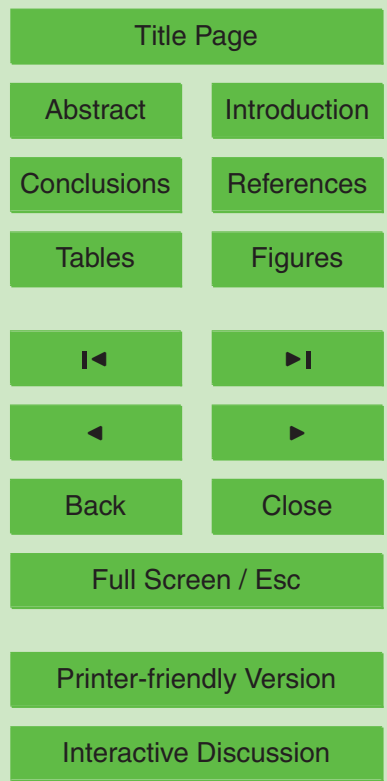


villages.

We think that the success of Management Committees of Boring in rural environment in Senegal can act as a springboard, and as an example in villagers' participation for the management of water resources and hydraulic works (pumps). These

5 Management Committees were institutionalized by an inter-ministerial circular $n^{\circ} 1$ of 9 January 1984 in order to organize users' participation in the management of their water resources. So the Management Committee is defined as a non profitable associative structure of public utility constituted by the users of a drilling. Created on the occasion of a general meeting of all users, and convened by a local administrative authority, the Committee is managed by an executive board whose members can range from four to twelve. These Management Committees constitute, as reported in several studies (Kaba and Aubourg, 1998; Champetier, 1999), real participative structures which broadly contributed to the promotion of the village self-management as regards pumping stations. The installation of these Management Committees instead of the old structures (CLC and CNC) within the framework of river waters management could allow a larger involvement and responsibility among the riverside local populations. These Committees constitute a reference due to the role they could play in resolving the watershed problem by assuring a better concerted management of the waters of the river.

Besides CPE which seems to favour big users to the detriment of small users in terms of participation in decision-making in the water management of the river, one could create a new special structure of animation, training and sensitization whose main role would be to ensure: the technical support and the coordination of the activities of Management Committees and the elaboration, execution, and monitoring of the programs of training, animation and users sensitization. This training and sensitization stage seems inevitable to achieve real populations participation in decision-making in the management of river water.

HESSD

4, 1917-1946, 2007

Analysis of the Senegal River watershed management

A. M. Sène et al.

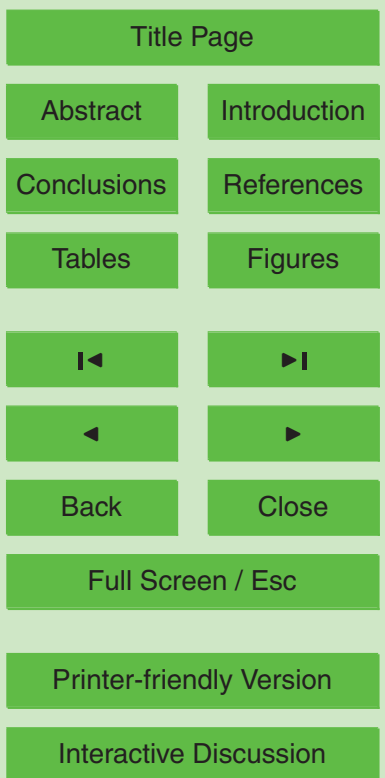




\section{Conclusions}

This study shows the goodwill of the States concerned with the watershed of the Senegal River to work together for a development of the resources of the river. The creation of the OMVS, a real tool of integration, is an obvious proof: this organization stimu5 lates inter-States collaboration for the development of regional exchanges and for the achievement of common plans. Despite the withdrawal of Guinea (where the river rises in) at the beginning of 1960s and the painful events between Mauritania and Senegal in 1989 among other difficulties encountered by the riverside States in the common management of the river, the organisation survives and shows the willingness of collaboration and solidarity between States members of the OMVS nowadays. This organization, because of the "international" dimension of the river, carried out important works (the dams of Diama and Manantali).

Incidentally, as regards the principle of public participation in decision-making, this study shows distinctly that the main conventional texts developed within the framework of the river water management referring to this principle are marked by their novelty and the difficulty to be put into practice. However, the Charter of waters (2002), the most recent convention ratified by the member States of the OMVS, takes this principle much more into account. Efforts had been made by the member States to insert this principle, a principle that has been more significantly emphasized these last years on the international scale through important conferences or through international conventions (Agenda 21, Convention on the Law of the Non-Navigational Uses of International Watercourses ....).

Today, the major expected improvement towards a better local development is to take into consideration the small users of the river and at the micro-local scale as a space of life that should be respected and make it politically alive. They know that even in France, the pioneer of an integrated management of water (Committees of Basin created by the law of 1964), the participation of the small users in the policies of river development and their representation is very weak (Bonin and al., 2006).

\section{HESSD}

4, 1917-1946, 2007

Analysis of the Senegal River watershed management

A. M. Sène et al.

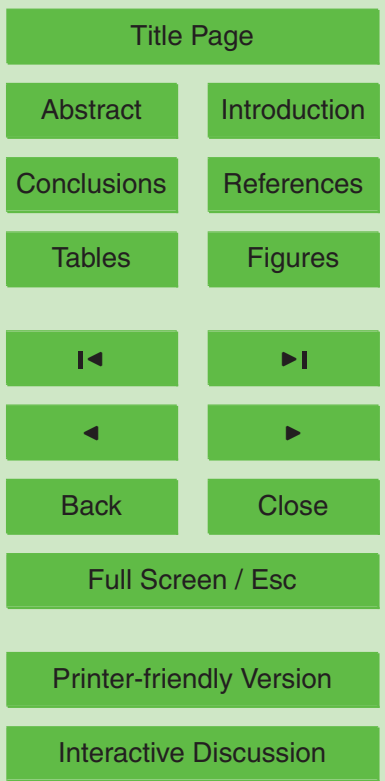


In France, the institutionalization of public debates on water and the development of forums on the Internet would allow theoretically the political representation of this category of uses, yet the efficiency of this progress is very weak. Numerous are the voices which rise to alert to or criticize the procedures of participation set at the very early 5 stages of plan preparation. These results in guilty negligence on the non-intentional or expected effects of action and this can be described as anaesthesia of thought development (Soubeyran, 2006). Works and theoretical principles of the kind prove to be ancient, notably in developing countries. They are broadly applied on the scale of micro-plans today, but they remain unknown to a great extent as far as management is 10 concerned, basically at the scale of the watersheds.

The realization of the OMVS objective as to the absence of the participation of the local populations in decision-making and its willingness to insert and to adapt the international juridical instruments relating to international watercourses in the management of the Senegal River constitutes, at any rate, promising elements for the future.

\section{References}

Aubert, S.: La gestion patrimoniale des ressources forestières à Madagascar : Limites et perspectives d'une "révolution par le haut". In Patrimonialiser la nature tropicale. Dynamiques locales, enjeux internationaux, edited by: Cormier-Salem, M. C., Juhé-Beaulaton, D., Boutrais, J., and Roussel, B., IRD, Paris, 101-104, 2002.

20 Baldé, M. L.: L'aménagement des périmètres intermédiaires de la moyenne vallée du fleuve Sénégal, Thesis on rural study, university of Toulouse-Le-Mirail, 111-113, 1999.

Baré, J.-F.: Une pensée positive ? Anthropologie sociale et développement rurale, L'Homme, $\mathrm{n}^{\circ} 131,129-136,1994$.

Baré, J.-F. (Ed.): Regards interdisciplinaires sur les politiques de développement, L'Harmattan,

\section{Paris, 1997.}

Bonin, S., Blanc, N., Chartier, D., Marcant, O., Arnaud de Sartre, X., Navaro, R., and Sène, A. M.: Le fleuve, un instrument du développement durable, Final report, Programme PUCAMEDD: Politiques territoriales et développement durable, 25-100, 2006.

\section{HESSD}

4, 1917-1946, 2007

Analysis of the

Senegal River

watershed

management

A. M. Sène et al.

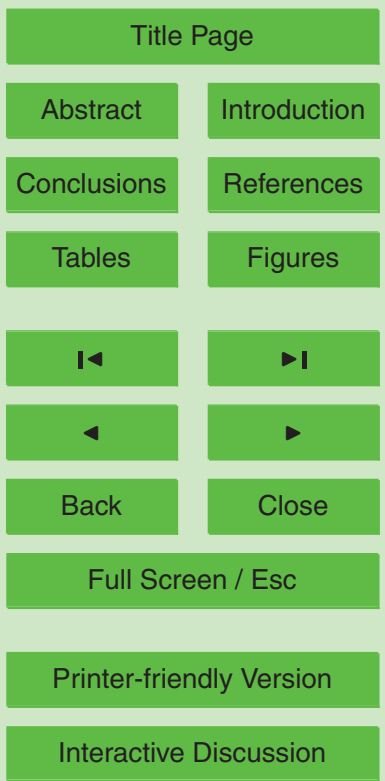


Caubet, C. G.: L'impact des grands barrages, Ecologie et Politique, ed. Sylleps, 25, 77-87, 2002.

Cernea, M.: La dimension humaine dans les projets de développement. Les variables sociologiques et culturelles, Karthala, Paris. $1^{\circ}$ éd. Anglais 1991, Putting people first. Sociological variables in rural development, Oxford University Press, Oxford, 1998.

Champetier, S.: Gestion des ouvrages d'approvisionnement en eau potable du bassin du fleuve Sénégal, Actes de la rencontre du 14/11/1998 à Lille, Ed. ISF, pS-Eau, 1999.

Cling, J. P., Razafindrakoto, M., and Roubaud, F.: Les nouvelles stratégies internationales de lutte contre la pauvreté, DIAL, Economica, Paris, 2002.

10 Coly, A. and Niang, A.: Mobilisation paysanne et gestion de l'eau (lac de Guiers Sénégal), in: Administrer l'environnement en Afrique, edited by: Compagnon, D. and Constantin, F., Karthala-Ifra, 271-273, 2000.

Coly, A.: Enjeux de la participation des collectivités locales à la gestion intégrée des eaux du fleuve Sénégal, Les cahiers du Girardel, 1, Saint-Louis, Sénégal, 23-25, 2003.

D'Aquino, P. and Seck, S. M.: Vers de nouveaux enjeux pour le développement territorial décentralisé : leçons d'une expérience au Sénégal, Les cahiers du Girardel, 1, Saint-Louis, Sénégal, 40-42, 2003.

Dubosc, A.: La participation du public dans les processus de prise de décision liés à l'eau, Agence de l'eau Seine-Normandie, 2-4, 2001.

20 Dupré, G. (Ed.): Savoirs paysans et développement,Karthala, Paris, 1990.

Eldin, E. and Milleville, P. (éd.): Le risque en agriculture,ORSTOM, coll. A travers champs, Paris, 1989.

Engelhard, P.: La vallée "revisitée" ou les "Enjeux de l'après-barrage" cinq ans plus tard, in: La vallée du fleuve Sénégal : évaluations et perspectives d'une décennie d'aménagements, edited by: Crousse, B., Mathieu, P., and Seck, S. M., Ed. Karthala, Paris, 45-79, 1991.

Eyben, R. and Ladbury, S.: Popular Participation in Aid-assisted Projects: Why more in Theory than Practice? In Power and Participatory Development. Theory and Practice, edited by Nelson and Wright, Intermediate Technology Publications, 192-200, 1997.

Fall, S. M., Traore, M. B., and Sène, S.: Problématique de la participation du public à la gestion du fleuve Sénégal, UICN, Saint-Louis, Sénégal, 30-37, 2001.

Grawitz, M.: Méthodes des sciences sociales, Dalloz, 11ème édition, Paris, 770-771, 2001.

Guerber, F.: Etude de gestion des Ouvrages Communs de l'OMVS-Observation sur les Rapports Provisoires de Phase 2, OMVS, Haut-Commissariat, Dakar, 6-24, 1986.

HESSD

4, 1917-1946, 2007

Analysis of the

Senegal River

watershed

management

A. M. Sène et al.

Title Page

Abstract

Introduction

Conclusions

Tables

References

Figures

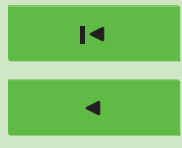

$\rightarrow$ I

Back

Close

Full Screen / Esc

Printer-friendly Version

Interactive Discussion 
Hussein, K.: Participatory Ideology and Practical Development: Agency Control in a Fisheries Project, Kariba Lake. In Power and Participatory Development. Theory and Practice, edited by Nelson and Wright, Intermediate Technology Publications, 170-180, 1997.

Kaba, O. and Aubourg, G.: Actes de la deuxième rencontre de concertation des acteurs dans le domaine de l'hydraulique au Sénégal (1997), pS-Eau - DEM - RADBF, 30-44, 1998.

Kiss, A.: Introduction au droit international de l'environnement, Unitar, Genève, Suisse, 1-21, 1997.

Kiss, A. and Shelton, D.: Evolution et principales tendances du droit international de l'environnement, UNITAR, Genève, Suisse, 19-45, 2001.

10 Koné, A. K.: Gestion du bassin du fleuve Sénégal: L'OMVS plaide pour la vulgarisation de la charte, L'indépendant, 12/09/2006, dossier Economie, http://www.maliweb.net/category. php?NID=13782, 2006.

Labranche, S. et Warin, P.: La concertation du public, Intermediate report, programme de recherche Concertation, Décision, Environnement, http://www.unites.uqam.ca/sqsp/pdf/ congresAnn/congres2004_labranche-warin.pdf, 2003.

Lane, J.: Non-governmental Organizations and Participatory Development: the Concept in Theory versus the Concept in Practice. In Power and Participatory Development. Theory and Practice, edited by Nelson and Wright, Intermediate Technology Publications, 181-91, 1997.

Lecornu, J.: Les barrages et la gestion des eaux, Conférence Internationale: Eau et développement durable, UNESCO, Paris, 1998.

Lericollais, A.: Risques anciens, risques nouveaux en agriculture paysanne dans la vallée du Sénégal. In Le risque en agriculture, edited by Edlin, M. and Milleville P., ORSTOM, Paris, 419-436, 1989.

Levy, M.: Comment réduire pauvreté et inégalités : Pour une méthodologie des politiques publiques, IRD, Karthala, Paris, 2002.

Salem-Murdock, M., Niasse, M., Magistro, J., Nuttal, C., Horowitz, M. M., Kane O. avec Grimm C., and Sella, M.: Les barrages de la controverse: Le cas de la vallée du fleuve Sénégal, Ed. L'Harmattan, Binghamton, New York, 11-62, 1994.

30 Mathieu, P.: Irrigation et associations locales à Madagascar. Jeux et enjeux d'un transfert de gestion aux organisations paysannes, in: Politiques agricoles et initiatives locales. Adversaires ou partenaires, edited by: Blanc-Pamard, C., ORSTOM, Paris, 239-259, 1993.

Mvondo, S. A.: Dynamique de gestion transfrontalière des forêts du bassin du Congo: Une

HESSD

4, 1917-1946, 2007

Analysis of the

Senegal River

watershed

management

A. M. Sène et al.

Title Page

Abstract

Introduction

Conclusions

References

Tables

Figures

14

Back

Full Screen / Esc

Printer-friendly Version

Interactive Discussion 
analyse du traité relatif à la conservation et la gestion des écosystèmes forestiers d'Afrique Centrale, 2/1 Law, Environment and Development Journal, 115-117, 2006.

Nelson, N. and Wright, S.: Participation and Power. In Power and Participatory Development. Theory and Practice, edited by Nelson and Wright, Intermediate Technology Publications, 1-18, 1997.

OMVS: Analyse des contraintes liées à la culture de décrue, Programme d'Optimisation de la Gestion des Réservoirs (POGR), Phase 3, Annexe 1, 1-34, 2001.

OMVS: Recueil d'instruments juridiques relatifs au fleuve Sénégal, Dakar, Sénégal, 3-7, 2006.

OMVS and IRD: Impacts potentiels de la gestion des ouvrages et des eaux de surface du fleuve Sénégal sur l'agriculture irriguée, Rapport de synthèse, in: Etude d'optimisation de la gestion des réservoirs du fleuve Sénégal (POGR), Dakar, Sénégal, 20-22, 1999.

Roche, D.: Le développement local en milieu rural: De quoi parle-t-on ? Les cahiers du Girardel, 1, Saint-Louis, Sénégal, 84-86, 2003.

Scoones, I. and Thompson, J. (Ed.): La reconnaissance du savoir rural. Savoir des populations, recherche agricole et vulgarisation, CTA-Karthala, Paris, 1999.

Sène, A. M.: Stratégie d'acteurs et développement durable dans la vallée du fleuve Sénégal: Quelle durabilité pour quel type d'acteur ? Seminary on arid and semi-arid area, Institut de Géographie Alpine, University of Grenoble 1, 10-16, 2006.

Soubeyran, O.: Pensée aménagiste et tautologies, http://www2.unine.ch/webdav/site/inst_ geographie/shared/documents/EcoleDoctorale/Tautodef.pdf (Doctoral school of Neuchatel University), 2006.

Tangara, D.: Défis du développement régional et dynamique des politiques d'aménagement du bassin du fleuve Sénégal, Thesis on tropical spaces, univ. Bordeaux III, 555-557, 1998.

World Bank: Mid-term review of the OMVS Regional Hydropower Project Senegal, April10-21, 2000, Back-to-Office-Report, Washington DC, World Bank, 2000.

World Commission on dams: Dams and development: A new framework for decision-making, The report of the World Commission on dams, Earthscan Publications Ltd, London and Sterling, VA, 2000.

\section{HESSD}

4, 1917-1946, 2007

Analysis of the

Senegal River

watershed

management

A. M. Sène et al.

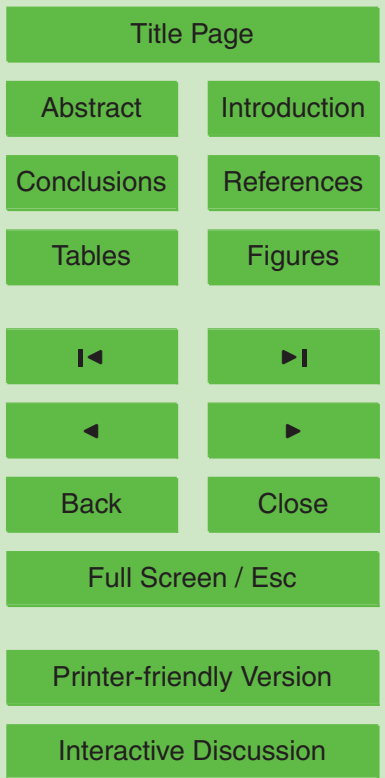




\section{HESSD}

4, 1917-1946, 2007

Analysis of the Senegal River watershed management

\begin{tabular}{cc}
\hline Dates & Conventions \\
\hline Conventions signed after the construction of the dams \\
\hline 28 May 2002 & $\begin{array}{c}\text { Charter of waters } \\
\text { Creation of the Agency of Management and Exploitation } \\
\text { of the Diama (SOGED) }\end{array}$ \\
7 January 1997 & Creation of the Agency of Management of Power of the \\
& Manantali (SOGEM) \\
\hline Conventions signed before the construction of the dams \\
\hline 15 May 1982 & Modalities of Financing Common Works \\
& Legal Status of the Common Works \\
11 March 1972 & $\begin{array}{c}\text { Status of the Senegal River } \\
\text { Creation of the OMVS }\end{array}$ \\
\hline
\end{tabular}

A. M. Sène et al.

Title Page

Abstract Introduction

Conclusions References

14

4

Back

Close

Full Screen / Esc

Printer-friendly Version

Interactive Discussion 


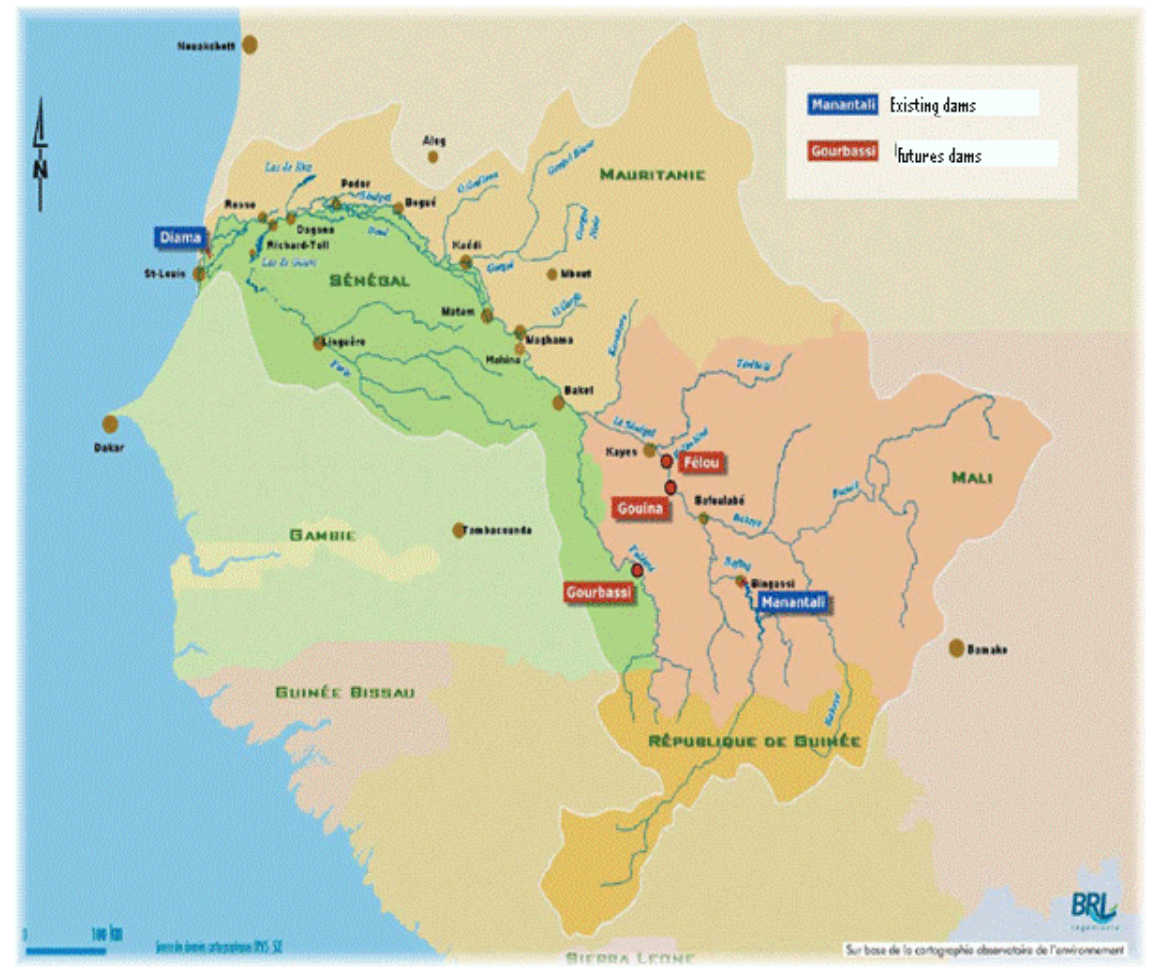

\section{HESSD}

4, 1917-1946, 2007

Analysis of the Senegal River watershed management

A. M. Sène et al.

Title Page

Abstract

Conclusions

\section{Tables}

14

4

Back

Full Screen / Esc

Printer-friendly Version
Fig. 1. Geographical map of the Senegal River watershed (Source: OMVS). The riverside States of the Senegal River watershed are: Senegal, Mauritania, Mali and Republic of Guinea. The two dams of Diama and Manantali and the next projects of dams are represented on this map. 


\section{INTERNATIONAL CONVENTIONS}

- Convention on Access to Information, Public Participation in decision-making, and Access to Justice in Environmental

International scale Matters, Principle 6, Aarhus, 06/1998

- Declaration on environment and sustainable development, Principle 10, Rio, 06/1992

- Convention on the Law of the Non-Navigational Uses of International Watercourses, New York, 05/1997

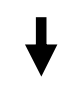

Regional scale
(Senegal river watershed)

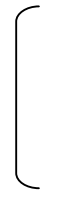

REGIONAL CONVENTION

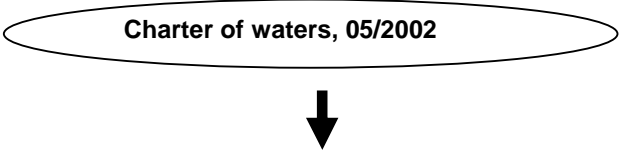

NON STATE LOCAL ACTORS

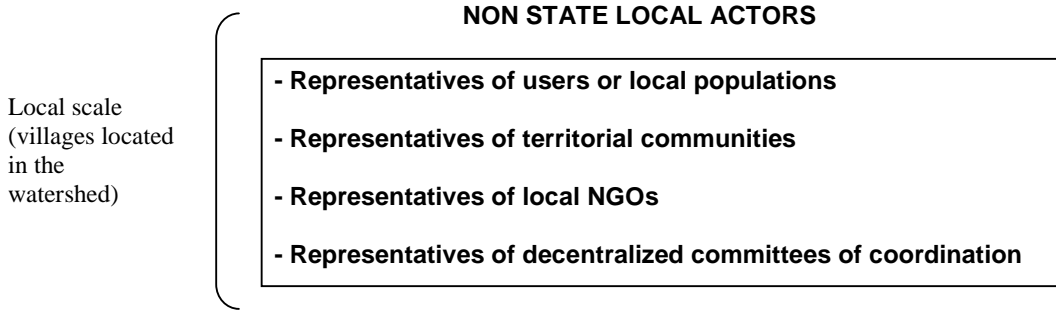

1 Direction of influence

Fig. 2. Influence, in public participation, of the international Conventions on the Charter of waters and this one on the non state local actors. Some international instruments which treat the question of participation inspired Charter of waters. This one invited non state local actors to participate in river water management activities.
HESSD

4, 1917-1946, 2007

Analysis of the Senegal River watershed management

A. M. Sène et al.

Title Page

Abstract Introduction

Conclusions References

Tables Figures

14

$>$ I

4

Back

Close

Full Screen / Esc

Printer-friendly Version

Interactive Discussion 


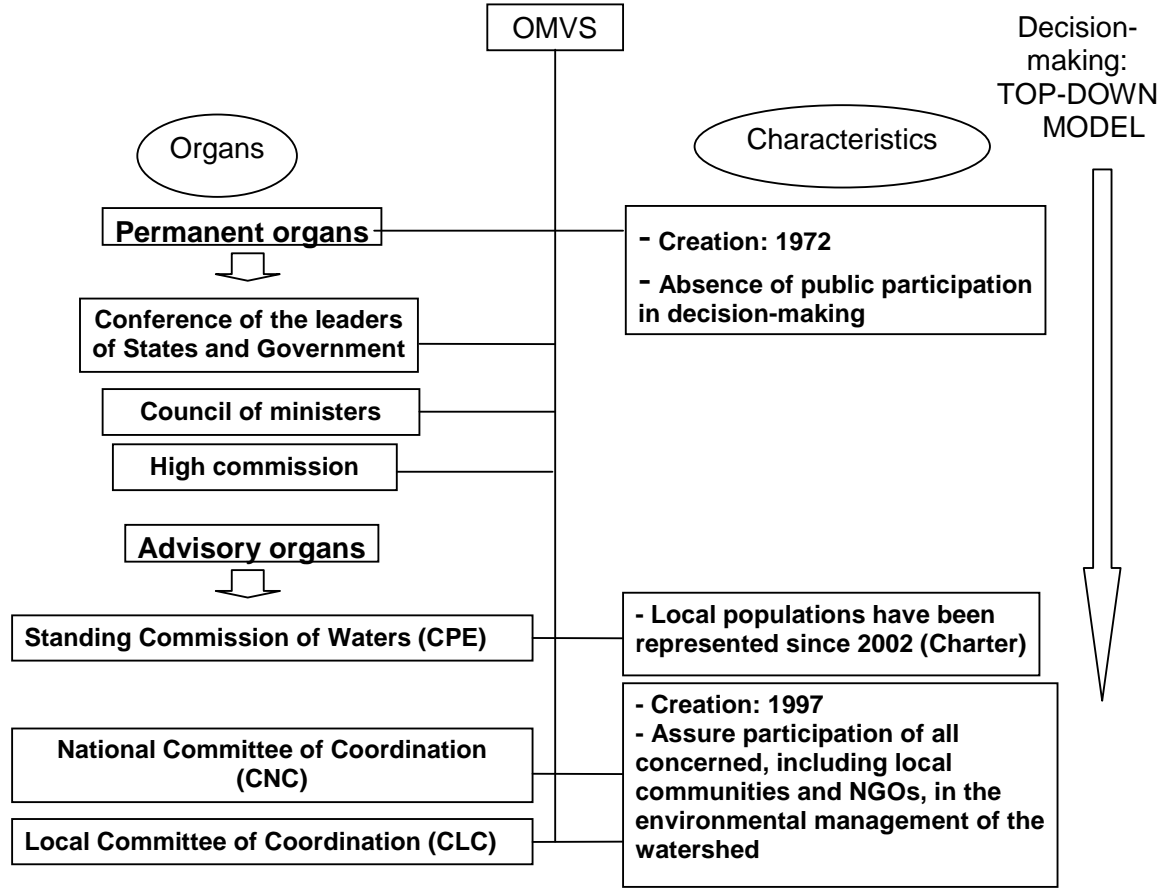

Fig. 3. Institutional frame of water management of the Senegal River. The institutional mechanisms set up in the watershed of the Senegal River revolve around the creation of OMVS (a regional organization), responsible for the management of the river and its different organs: Permanent organs (Conference of the leaders of States and Government, Council of ministers and High commission) and advisory organs (CPE, CLC and CNC). Permanent organs are characterized by the absence of public participation in decision-making whereas advisory organs are characterized by the participation of local communities and NGOs, in the environmental management of the watershed. These results show a "top down" model of management where the OMVS centralizes all decisions to the detriment of the local populations.

\section{HESSD}

4, 1917-1946, 2007

Analysis of the Senegal River watershed management

A. M. Sène et al.

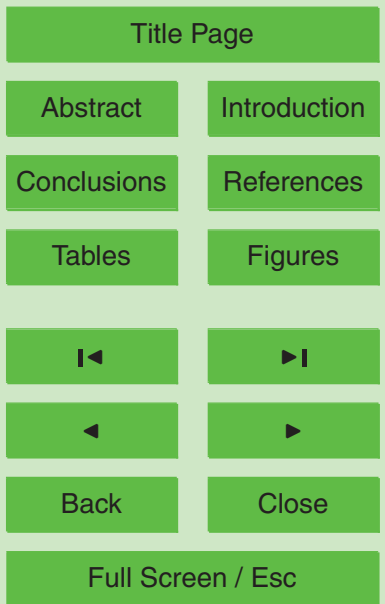

Printer-friendly Version

Interactive Discussion 